

ISSN: $2619-9548$

Journal homepage: $\underline{w w w . j o g h a t . o r g, ~} \underline{\text { http://dergipark.gov.tr/joghat }}$

Journal of Gastronomy, Hospitality and Travel (JOGHAT)

2019 - Volume: 2 Number: 2

Page: $134-140$

Received: 09.12 .2019

Revised: 19.12 .2019

Accepted: 21.12 .2019

\title{
Research Article \\ HOLIDAY-INSPIRED AGRITOURISM IN THE U.S.: THE CASE FOR EXAMINING THE PHENOMENA THROUGH A GASTRONOMIC LENS
}

\author{
Alana SEAMAN ${ }^{1}$ (orcid.org/0000-0002-3580-8531) \\ Ph.D., Assistant Professor of Recreation, Sports Leadership, \& Tourism Management \\ University of North Carolina Wilmington - Wilmington, NC, USA
}

\begin{abstract}
Halloween, Christmas, and even Easter have become colossal cultural and economic phenomena. An increasingly popular aspect of these holidays is participation in agritourism experiences. While the original links between agricultural traditions, gastronomy, and the holidays were once direct and clear, today the relationships between food, agritourism, and holiday traditions are dramatically different. Food still plays an important role, however, the relationship between contemporary holiday agritourism rituals and the food eaten, and food-products purchased during the excursions has become indirect, obscured by industrialization and commercialism. Given the growing popularity and importance of agritourism and entertainment-farming, and the sacred place of both food and holiday traditions in society, an exploration of holiday-inspired agritourism through a gastronomic lens is timely and could reveal important factors contributing to rural tourismdevelopment, placemaking, cultural and culinary heritages, and sustainability, and yield information about how these practices shape participants' perceptions of agriculture, food-production, agrarian society, and class.
\end{abstract}

Keywords: Agritourism, Culinary Heritage, Holidays, Christmas, Halloween, Food, Rural Tourism

\section{Introduction}

Halloween, Thanksgiving, Christmas, and even Easter have become colossal cultural and economic phenomena (National Retail Federation, 2019). An increasingly popular aspect of these holidays, in the U.S. in particular, is participation in agritourism experiences (see for example George, 2018; Malcom, 2019; Tuggle, 2019; Young, 2019; White, 2019). People venture out into the countryside in droves for short daytrips in the days and weeks surrounding important seasonal holidays to engage in rituals largely born from historic food production and consumption practices. While the original links between seasonal sowing and harvest traditions, agricultural events, food, and the holidays were once both direct and clear, today the relationships between food, agritourism, and holiday traditions associated with Christmas, Thanksgiving, Halloween, Easter, and the like are dramatically different. Gone are the days when farmers and rural community members would come together to participate in a

\footnotetext{
${ }^{1}$ To cite this document: Seaman, N. A. (2019). Holiday-inspired Agritourism in the U.S.: The Case for Examining the Phenomena through a Gastronomic Lens, Journal of Gastronomy Hospitality and Travel, 2(2), 134-140. DOI: 10.33083/joghat.2019.22
}

Corresponding author: seamana@uncw.edu 
meaningful celebration of the local land's harvest, feasting on foodstuffs grown, raised, picked, and culled in the immediate area. Instead today, Americans in particular pack up the family, drive to a nearby entertainment farming destination and, in addition to picking out the perfect (often trucked-in) pumpkin, engage in the eating of oversized (and outsourced) smoked turkey legs and various iterations of caramel apples (grown in part off-site), the drinking of ciders and hot cocoas (frequently from pre-made concentrates or poured from plastic jugs), and the perusing and purchasing of agricultural- and homemade-themed food products... despite the fact that many of the foods, drinks, and products are often produced, en masse, elsewhere (see for example Fickling, 2019). In short, though food still clearly plays an important role in these annual treks, the relationship between contemporary agriculturebased holiday tourism rituals and the food eaten, and food products purchased during the excursions has become mottled, indirect, and obscured by industrialization, commercialism, simulacra, and modernity.

Visitors may simply have a taste for nostalgic culinary traditions caring little about the authenticity or sourcing of the edibles they procure and consume as central components of their Halloween, Thanksgiving, Christmas, and Easter agritourism celebrations, however this seems out of line with typical agritourism practices (such as when visitors go to wineries specifically to taste the wine made from grapes grown on the property), and the recent wave of neolocalism wherein people are increasingly interested in all things local (Eberts, 2013), particularly food (Adams and Adams 2011; Adams \& Salois 2010; Casselman 2010; Delind 2006; Giovannucci et al. 2010; Richards 2012; Timmons 2006; Sims 2009). Either way, food items play a seemingly important role in both the unique and increasingly popular celebratory holiday agritourism phenomena, as well as modern holidays more generally, despite what appears to be a somewhat sharp departure from their original closely linked meanings. Given the intimate yet complicated relationship between food, modern seasonal holidays, and agritourism, and the growing popularity and importance of agritourism and entertainment farming (Frumkin et al., 2017; Veeck, Che \& Veeck, 2006) as a means of supplementing the finances of farmers faced with increasingly unpredictable crop yields (Frumkin et al., 2017; McGehee \& Kim, 2004), an exploration of holiday-inspired agritourism through a gastronomic lens is both timely and relevant. Such an approach could reveal important factors contributing to rural tourism development, placemaking, cultural and culinary heritages, and sustainability, as well as clarify how these practices work to shape participants' perceptions of agriculture, food production, agrarian society, and class.

\section{Seasonal Holidays}

Holidays are an important part of society and culture. They reinforce shared and collective values and allow participants to cultivate a sense of belonging (Rogers, 2002). Laden with nostalgia, ritual, and immersive and emotional experiences, holidays are closely bound to specific intangible feelings, childhood, family, and religion, rendering the experiences associated with them particularly potent and memories of them long-lasting (Larkin, 1999). Similarly, experiences involving food can elicit deep emotional ties because of their immersive and social components that in turn, also create powerful and often permanent images of associated people, places, and talismans (Hirsh, 1992; Ramshaw \& Gammon, 2005). In short, holiday traditions, particularly those involving food create enduring and deeply entrenched perceptions about specific traditions, culinary traditions, physical settings, sights, smells, sounds, and other associated social and physical elements.

Historically, the origins of many seasonal holidays are closely tied to agricultural patterns and, in turn, food. Halloween for instance traces its beginnings to the Celtic (or pre-Christian, also known as Pagan) celebration of Samhain. Esentially an agricultural festival (MacCulloch in Rogers, 2002), the tradition focused largely on the Feast of Beltane wherein the year's harvest was celebrated, and, with the darkest part of the year approaching (when everything appears to die off), the spirits were honored and a plan was made for feeding the population through the winter. The ubiquitous Jack O' Lantern was, in historic times, cut out of fresh locally available root vegetables (mostly turnups or potatoes) and lit with candles to honor or "light up' the hollow spirit of "Jack" (a man who tricked the devil twice and was thus left to wonder soulless and empty between worlds - an apt metaphor for the dead of Winter that empties pantries and grain bins alike) (Belk, 1990). The tradition endures today, though anecdotal evidence suggests that few of the many millions of people that travel to area farms to seek out and carve pumpkins each year have any understanding of the tradition's original links to food, agriculture, or religious beliefs (Belk, 1990). 
While Thanksgiving has obvious links to the fall harvest and feasting on the season's bounty, the Pagan celebrations that would eventually become Christmas were similarly born from traditions surrounding the natural growing and harvest seasons. Pre-Christian groups held feasts near the shortest days of the year (usually mid- to late- December) to enjoy the fresh meat from animals culled before the depths of winter set in (to thin the herd so as to not have to feed too many livestock during the harshest months), and the libations readied from the fermenting of crops harvested in the Fall (Forbes, 2008). Iterations of the culinary customs undertaken around Winter's solstice were common in various cultures across the known world, making the annual ritual ripe for streamlining and adapting into a Christian belief system as the region spread (Forbes, 2008). Despite being imbued with icons of Jesus and Krampus, St. Nick and candy canes, and tales of wise men, flying reindeer, elves, and talking snowmen, or whatever else Christmas now encompasses, the holiday has undeniable agricultural roots. Similarly and unsurprisingly, Easter was originally a way to pay tribute to nature's Spring rebirth, the sowing of the year's crops, and the emergence of young livestock. Easter baskets in particular harken back to the days when the first seedlings of Spring would be collected and delivered in weaved vessels to local sacred sites in hopes of honoring nature's reawakening and ensuing a healthy growing season (Morrill, 2009).

\section{Agritourism \& Entertainment Farming}

While they may have strayed from their original agricultural-bound meanings, seasonal holidays are today as popular as ever having both religious and secular appeal and prompting consumers to spend billions of dollars each year on related purchases (-and that's just in the U.S.). In fact, estimates indicate that in 2019, Americans will spend $\$ 727.9$ billion on Christmas alone, despite having already spent $\$ 8.8$ billion on Halloween, and even a whopping $\$ 18.11$ billion on the less popular (though still widely celebrated) Easter holiday (National Retail Federation, 2019). Thus, it is perhaps no wonder that farmers are increasingly taking advantage of opportunities to cash in on the holiday spending phenomena particularly as agritourism in general is becoming more popular (MeHee \& Kim, 2004) and more small farms are becoming dependent upon the revenue generated from entertainment farming activities (in order to supplement inherently fickle agricultural product-based profit streams) (Frumkin et al., 2017). McGehee and Kim (2004) explain that wherein one bad storm can wipe out an entire crop, and in turn, a large chunk of a farmer's annual salary, agritourism and farm entertainment provide a stable source of income. In fact, weddings, farm dinners, barn dances, hay rack rides, and harvest experiences (such as grape crushing for wine) represent a central form of income for many small farms and act as the lifeblood that keeps them operating (McGehee \& Kim, 2004). The entrepreneurial endeavors also bring tourists and financial vibrancy to otherwise often struggling rural communities (where, in many cases other industries such as mills, mines, and textiles plants have disappeared, and numerous mid-size farms and ranches have been sold off) (VanSandt, Thilmany \& McFadden, 2016; Veeck, Che \& Veeck, 2006).

While scholars have examined which factors contribute to successful agritourism destinations (such as infrastructure, proximity to more densely populated areas and the types of population those areas are made up of, and proximity to other natural amenities) (Lucha et al., 2019; Veeck, Che \& Veeck, 2006), little if any research has considered the modern holiday-inspired agritourism travel phenomena, much the less the trend's relationship with food in general or specific foods in particular. However, positioned at the crux of neolocalism, the increasing recognition of food as an element of place (UNWTO 2017; Richards 2012), growing concern over corporate farming and thus interest in small farms and locally produced edible goods (Delind 2006; Feagan 2007), and the experience (see Pine \& Gilmore, 1998) and sharing economies (see Hamari, Sjoklint \& Ukkanen, 2015), the soaring popularity of the phenomena of rural holiday-specific tourism shows no signs of letting up anytime soon.

\section{Social \& Cultural Trends}

Neolocalism, or an increased interest in and demand for unique, place-specific experiences, and products (Eberts, 2013; Flack, 1997; Schnell \& Reese, 2014) particularly related to food (Adams \& Adams 2011; Adams \& Salois 2010; Casselman 2010; Delind 2006; Giovannucci et al. 2010; Richards 2012; Sims 2009; Timmons 2006), is a social reaction to the widespread opening, and more notably and recently, the closing of the big-box chain stores and restaurants that once dominated the American landscape and to some extent standardized the 
country's leisure, shopping, and eating habits. A widespread renewed interest in all things local is sweeping the nation and affecting many aspects of contemporary American society (Holtkamp et al., 2016; Schnell \& Reese, 2014). Anecdotal evidence suggests that the agritourism excursions associated with Christmas, Easter, and other seasonal holidays take place close to most participants' homes thus reinforcing the notion that "local" is in fact popular, and creating unique travel and consumption patterns as the largely locally- or regionally-based format of this type of tourism also seems to involve shorter timeframes than most travel. Anecdotal evidence suggests that due to the closer proximity of these destinations to travelers' homes the trips often exclude overnight stays. In turn, these travel experiences appear to be more social than other longer trips taken further away, as they are more feasible for larger groups of friends and family to engage in together than travel requiring extensive preplanning, time, and financial commitments.

Food is widely seen as a core dimension of place (Sims 2009; Richards 2012) and as such many tourists consider purchasing and eating local foods as central to destination experiences (UNWTO 2017; Richards 2012). In line with an increased interest in food, a growing percentage of people now also consider themselves 'foodies', or individuals who cultivate their identity in part from their relationship with growing, procuring, preparing, and/or consuming food (Ambrozas, 2003). Getz and Robinson (2014) explain that this expanding social group is often interested in learning about all aspects of food from its place in culture to its relationship with the environment (see also Green, 2013). Though foodies are not alone, as many scholars point out growing concerns amongst the general public as well about the practices and unsustainability of the current corporate dominated food system (Delind 2006; Feagan 2007). Thus, the food traditions associated with holiday-inspired agritourism experiences wherein traditional and home-made themed, albeit premade and commercially produced food items (such as pumpkin spice flavored sweets and cider mixes, seasonally flavored jams, various types of fudge, caramel candies, hot chocolate made from instant powder and water, and the like) co-mingle with locally and artisan made concessions and food goods (such as apple donuts fried on site, hard cider made from local produce, and craft pickled jars of regionally sourced vegetables, etc.) seem oddly juxtaposed to current trends focused on authentically local and small-batch made foodstuffs.

Perhaps visitors are more concerned with the activities that can be undertaken upon their holiday agritourism excursions, and the nostalgic and artificially 'homemade' food offerings available to holiday farm visitors are simply symbolic of the days of yore. The incorporation of agritourism experiences into holiday traditions is, after all, likely driven by the experience economy wherein people place significant value on experiences as opposed to goods and services (Pine \& Gilmore, 1998). Given the infrequent occurrence of each holiday, and the mystic and festive creative liberties afforded to the celebratory traditions, the experiences that can be cultivated via agritourism during these special times of year are, in fact often, unique and novel travel experiences distinctive from other rural tourism endeavors. Or, perhaps the authenticity of the food offerings is of little concern to visitors so long as they look authentically local and homemade particularly as the unique experiences engaged in during holiday-inspired travel to entertainment farm destination seem custom-made for the sharing economy (Hamari, Sjoklint \& Ukkanen, 2015; Spence, 2019). In an era where sharing every aspect of one's social, professional, and personal life online, rural settings, especially during the holidays, lend authentic agrarian aesthetics to insta-worthy snapshots, and novel activities provide participants with opportunities for unique action shots. Regardless, agritourism related to Halloween, Thanksgiving, Christmas, Easter, and other holidays will likely remain a popular component of peoples' annual celebrations, particularly in the United States, and food will no doubt continue to play an essential role in those experiences.

\section{Discussion \& Future Research}

Despite the widespread interest in seasonal holidays such as Halloween and Christmas, and the fact that agritourism experiences appear to be an increasingly common part of these traditions (for Americans in particular), the phenomena has received surprising little attention from scholars and thus little is known about this unique, yet incredibly and increasingly popular form of travel. Given that many holiday traditions stem from the food production and consumption practices associated with agrarian society, and that food still serves an important, though seemingly very different purpose in today's holidays and related agritourism experiences, interdisciplinary research is needed to explore the gastronomic components of the seasonal travel practice. 
The culinary aspects of the seasonal celebratory rural travel practices should be considered from both a cultural standpoint and an applied angle. Holidays are closely linked to culture and therefore holiday-inspired agritourism and the food related experiences cultivated during such travel likely leaves visitors with many deeply rooted impressions about associated people, places, and food items and traditions. Since both holiday and dining experiences are immersive, social and deeply personal, and powerful, these experiences may contribute to perceptions about not only the relationship between food production and agriculture, but may also work to authenticate a romanticized view of agrarian life... perhaps also fueling, in part, the distrust and disdain for corporate farming practices and entities described by Delind (2006) and Feagan (2007).

Exploring the phenomena through a gastronomic lens would be helpful in considering how food-based holiday agritourism experiences cultivate a sense of place and frames perceptions of not only agriculture and food production, but also food processing, distribution, and consumption. Why, for instance, when there is an overwhelming surge of interest in the sourcing, health benefits, and environmental impacts of food in general, do consumers willingly overlook the same facets of gastronomy when engaged in holiday agritourism experiences? Are their discerning tastes simply suspended based on the notion that if food is eaten or bought from a rural locale it must be local and craft-made in small batches and thus healthy and eco-friendly? These examinations may also yield a reflection of holidays in contemporary America and say something about their perceived authenticity, relevance, or sacredness. An examination of who participates in and/or has access to the experiences and the foodstuffs associated with annual rural holiday trips could also provide important clues about food, agriculture, agritourism, and class, as well as the place of modern holiday traditions in today's society. And, given how the perennial phenomena also likely produces unique consumption patterns and quick and seemingly short-lived demand for local foods (which may not be practically met by local destination farms alone) and other specific food products, and likely involve unique motivations for and constraints to participation in the phenomena, the tangible aspects regarding the use of resources, layout of supply chains, food webs, and the economics surrounding the distinctive rural travel trend related to seasonal holidays is also ripe for examination.

In addition to the gastronomy of this type of tourism, other important aspects should also be considered by tourism scholars. Given that these annual practices likely have huge physical and intangible impacts on specific areas and rural destinations, scholars should consider the stakeholders impacted by these once-per-year pilgrimages as little is known about the perceptions and concerns of locals neighboring holiday farm attractions. Further, due to the drastic influx of tourists to rural areas for short periods of time (often much shorter than a typical tourist season such as the ones that occur during summer, or ski seasons, or even the weeks-, and in some places months-long apple- and grape-picking season) the economic and infrastructure impacts of this type of tourism should be assessed. Little also appears to be known about the ecological impacts of planting specifically for holiday harvesting yet may be of interest to scholars and farmers alike. For instance, how sustainable are agricultural practices undertaken specifically for holiday tourists? What does an ideal crop rotation that will meet the needs of the plant and the paying public alike, look like? Farm owners looking to capitalize on holiday agritourism may also benefit from knowledge about which breed of corn is optimal for building corn mazes, tips about how to plant and till to yield a dense crop through which winding paths and dead ends can satisfactorily be cut; about which apple trees will produce the most aesthetically pleasing fruit fit for sharing in today's virtual social culture; or about how to grow easy-to-pick pumpkins. The use of animals in these rural holiday experiences also warrants investigation as specific animals are also often associated with rural holiday experiences (see for example Tuggle, 2019). Why for instance do visitors flock to Christmas tree farms with live reindeer? What ethical and practical factors do farmers consider before utilizing animals as holiday-specific attractions?

All things considered, modern holiday-inspired agricultural tourism (e.g. travel to pumpkin patches, Christmas tree farms, and holiday themed petting zoos and egg hunts) deserves consideration by scholars as a distinctive form of travel. Given how these practices are built on ancient agrarian agricultural practices and rituals, and today are still intimately connected to the procuring and consuming of specific food items as central components of the annual celebratory pilgrimages, gastronomy provides an apt lens through which to explore the rich and increasingly popular perennial social phenomena. 


\section{REFERENCES}

Adams, D. C., \& Adams, A.E. (2011). De-placing local at the farmers' market: Consumer conceptions of local foods. Journal of Rural Social Sciences 26(2): 74.

Adams, D. C., \& Salois, M.J. (2010). Local versus organic: A turn in consumer preferences and willingness-topay. Renewable Agriculture and Food Systems 25(4): 331-341. doi.org/10.1017/S1742170510000219

Ambrozas, D. (2003). Serious feast: Vancouver foodies in globalized consumer society (Doctoral dissertation, School of Communication-Simon Fraser University).

Belk, R.W. (1990). Halloween: An evolving American consumption ritual. Advances in Consumer Research, 17.

Boyce, B. (2013). Trends in farm-to-table from a sociological perspective. Journal of the Academy of Nutrition and Dietetics 113(7): 895.

Casselman, A.L. (2010). Local foods movement in the Iowa catering industry. (Master's Thesis, Iowa State University).

Delind, L.B. (2006). Of bodies, place, and culture: Re-situating local food. Journal of Agricultural and Environmental Ethics 19(2): 121-146. doi 10.1007/s10806-005-1803-Z

Eberts, D. (2013). Neolocalism and the branding and marketing of place by Canadian microbreweries. In Patterson, M. \& Hoalst-Pullen (eds.). The Geography of Beer: Regions, Environment, and Societies. New York, NY: Springer.

Farsani, N.T., Ghotbabadi, S.S., \& Altafi, M., (2019). Agricultural heritage as a creative tourism attraction. Asia Pacific Journal of Tourism Research, 24(6), 541-549.

Feagan, R., Morris, D., \& Krug, K. (2004). Niagara Region Farmers' Markets: Local Food Systems and Sustainability Considerations. Local Environment 9(3): 235-254. doi.org/10.1080/1354983042000219351

Feagan, R. (2007). The place of food: Mapping out the 'local' in local food systems." Progress in Human Geography 31(1): 23-42. doi.org/10.1177\%2F0309132507073527

Fickling, D. (2019). More Thanksgiving pecans will be made in China. The Washington Post. Retrieved from https://www.washingtonpost.com/business/more-thanksgiving-pecans-will-be-made-inchina/2019/11/27/de018296-1105-11ea-924c-b34d09bbc948_story.html

Flack, W. (1997). American Microbreweries and Neolocalism: "Ale-ing" for a Sense of Place. Journal of Cultural Geography, 16(2), pp. 37-53.

Forbes, B.D. (2008). Christmas: A Candid History. Berkeley, CA: University of California Press.

George, R. (2018). An a-peel-ing new attraction: Vala's opens Friday. Omaha.com. Retrieved from https://www.omaha.com/sarpy/gretna/an-a-peel-ing-new-attraction-vala-s-opens-friday/article 4514c2ff3189-5841-ba65-887d81f11f1f.html

Getz, D., \& Robinson, R.N. (2014). Foodies' and their travel preferences. Tourism Analysis 19(6): 659-672. doi.org/10.3727/108354214X14116690097693

Getz, D., \& Robinson, R.N. (2014). Foodies and food events. Scandinavian Journal of Hospitality and Tourism 14(3): 315-330. doi.org/10.1080/15022250.2014.946227

Getz, D., Robinson, R., Andersson, T. \& Vujicic, S. (2014). Foodies and Food Tourism. Oxford: Goodfellow Publishers.

Giovannucci, D., Barham, E. \& Pirog, R. (2010). Defining and marketing "local” foods: Geographical indications for US products." The Journal of World Intellectual Property 13(2): 94-120. doi.org/10.1111/j.17471796.2009.00370.x

Gyimothy, S. \& Mykletun, R. (2009). Scary food: Commodifying culinary heritage as meal adventures in tourism. Journal of Vacation Marketing, 15(3), pp. 259-273.

Hamari, J., Sjoklint, M. \& Ukkonen, A. (2015). The sharing economy: Why people participate in collaborative consumption. The Association for Information Science and Technology.

Hirsch, A.R. (1992). Nostalgia: A neuropsychiatric understanding. Advances in Consumer Research, 19, pp. 390395.

Holtkamp, C., Shelton, T., Daly, G., Hiner, C. C., \& Hagelman III, R. R. (2016). Assessing neolocalism in microbreweries. Papers in Applied Geography, 2(1), 66-78.

Kim. (2019). 5 must-try foods at Vala's Pumpkin Patch. Oh My Omaha! [blog]. Retrieved from https://ohmyomaha.com/2019/09/food-at-valas-pumpkin-patch/

Larkin, M. (1999). Sniffing out memories of holidays past. The Lancet, 354(9196), 2142. 
Lefebvre, H. (1992). The Production of Space. Hoboken, NJ: Wiley-Blackwell.

Lowenthal, H.D. (1996). The Heritage Crusade and the Spoils of History. Cambridge, UK: Cambridge University Press.

Lucha, C., Ferreira, G., Walker, M.A., \& Groover, G. E. (2019). A geographic analysis of agritourism in Virginia.

Malcom, R. (2019). Apple Hill opens this weekend with traffic changes in place to ease congestion. CBS 13 Sacramento. Retrieved from https://sacramento.cbslocal.com/2019/08/16/apple-hill-traffic-changes/

McGehee, N. G., \& Kim, K. (2004). Motivation for Agri-Tourism Entrepreneurship. Journal of Travel Research, 43(2), 161-170.

Morrill, A. (2009). Easter, Passover \& Other Spring Festivals. New York: Infobase Publishers.

National Retail Federation. (2019). NRF Holiday Spending [Data Set]. Retrieved from https://nrf.com

Pine, B.J. \& Gilmore, J.H. (1998). Welcome to the Experience Economy. Harvard Business Review.

Ramshaw, G., \& Gammon, S. (2005). More than just nostalgia? Exploring the heritage/sport tourism nexus. Journal of Sport Tourism, 10(4), 229-241

Richards, G. (2012). "An overview of food and tourism trends and policies." In Food and the Tourism Experience: The OECD-Korea Workshop. 13-46.

Richards, G. (2015). "Evolving Gastronomic Experiences: From Food to Foodies to Foodscapes." Journal of Gastronomy and Tourism 1(1): 5-17. doi.org/10.3727/216929715X14298190828796

Rogers, N. (2002). Halloween: From Pagan Ritual to Party Night. Oxford: Oxford University Press.

Schnell, S. M., \& Reese, J. F. (2014). Microbreweries, place, and identity in the United States. In The Geography of Beer (pp. 167-187). Springer, Dordrecht.

Sims, R. (2009). "Food, Place and Authenticity: Local Food and the Sustainable Tourism Experience." Journal of Sustainable Tourism 17(3): 321-336.

Spence, M. (2019). Instagram drives growth in pick-your-own pumpkin farms. BBC News. Retrieved from https://www.bbc.com/news/uk-scotland-50223615

Timmons, D.S. (2006). Measuring and understanding local foods: The case of Vermont. Doctoral dissertation, University of Vermont.

Taun, Y.F. (1974). Topophilia: A Study of Environmental Perception, Attitudes, and Values. Englewood Cliffs, NJ: Prentice-Hall.

Tuggle, Z. (2019). Santa and reindeer highlight Christmas tree experience. Mansfield News Journal. Retrieved from https://www.mansfieldnewsjournal.com/story/news/2019/12/21/kleerview-farm-santa-reindeerhighlight-christmas-tree-experience/2677729001/

Van Sandt, A., \& Thilmany McFadden, D. (2016). Diversification through agritourism in a changing US farmscape. Western Economics Forum, 15(1837), 52-58.

Veeck, G., Che, D., \& Veek, A. (2006). America's changing farmscape: A study of agricultural tourism in Michigan. The professional geographer, 58(3), 235-248.

White, C. (2019). Spotlight: McLaurin Farms. Yes Weekly, Retrieved from https://yesweekly.com/spotlightmclaurin-farms/

Young, N. (2019). 12 Easter egg hunts to visit in Robertson County. Tennessean. Retrieved from https://www.tennessean.com/story/news/local/robertson/2019/04/08/12-easter-egg-hunts-visit-robertsoncounty/3384430002/ 